\title{
Evaluation of Streptomyces Common Scab Toxins Diffusion in Potato Tubers and through the Intestinal Barrier
}

\author{
Camille Leclerc $^{1}$, Arthur Zebré ${ }^{1}$, Jérémy Enault ${ }^{1}$, Pierre-Jean Racine ${ }^{1}$, Sandra Leblanc ${ }^{2}$, \\ Nathalie Connil $^{1}$, Pascal Svinareff ${ }^{2}$ and Marc G.J. Feuilloley ${ }^{1} *$ \\ ${ }^{1}$ Laboratory of Microbiology Signals and Microenvironment LMSM, EA 4312, \\ University of Rouen, Normandie, F-27000 Evreux, France \\ ${ }^{2}$ Biogalenys SAS, 9 rue de Pacy, F-27930 Miserey, France \\ *Corresponding author
}

\begin{tabular}{|c|c|}
\hline & A B T R A C T \\
\hline $\begin{array}{l}\text { Potatos, } \\
\text { Streptomyces } \\
\text { scabies, } \\
\text { Thaxtomin A, } \\
\text { Nigericin, } \\
\text { Bafilomycin A1, } \\
\text { Caco2/TC7 cells. }\end{array}$ & \multirow{3}{*}{$\begin{array}{l}\text { Streptomyces and particularly Streptomyces scabies the causative agent of common scab in } \\
\text { potato tubers are producing different toxins, including thaxtomin A, nigericin, } \\
\text { geldanamycin, tuncamycin and bafilomycin. Assay of these toxins in two potato strains } \\
\text { from the commercial circuit revealed that thaxtomin A can be detected in significant } \\
\text { amounts in scab surface lesions but also in the flesh of the tubers. Other toxins were } \\
\text { present under the detection limit of the assay. As thaxtomin A and other Streptomyces } \\
\text { toxins are thermostable, potato consumers can be exposed to these molecules. In order to } \\
\text { evaluate the potential effect of Streptomyces toxins on the intestinal barrier, their } \\
\text { cytotoxicity was studied in-vitro on Caco2/TC7 enterocytes. Except geldanamycin, all } \\
\text { other tested toxins showed significant cytotoxicity. Used at sub-lethal concentrations, } \\
\text { Streptomyces toxins were without effect on the transepithelial resistance of a model of } \\
\text { intestinal epithelium made by fully differentiated Caco } 2 / T C 7 \text { cells cultured in inserts. } \\
\text { However, measurements of the flow of these toxins through reconstructed intestinal } \\
\text { epithelium suggest that thaxtomin A, geldanamycin and tuncamycin could cross the } \\
\text { intestinal barrier. These results should deserve in-vivo studies to evaluate the real threat of } \\
\text { these toxins in regard of consumers. }\end{array}$} \\
\hline Article Info & \\
\hline $\begin{array}{l}\text { Accepted: } \\
\text { 17 April } 2017 \\
\text { Available Online: } \\
10 \text { May } 2017\end{array}$ & \\
\hline
\end{tabular}

\section{Introduction}

Streptomyces are well known filamentous Gram-positive bacteria, essentially present in soil and considered as non-pathogen for humans (Kämpfer, 2006). They produce a large diversity of bioactive molecules, including antibiotics, antifungal and even immuno-modulators and are of major industrial interest (Watve et al., 2001). However, several species of Streptomyces are phytopathogens and the first identified, Streptomyces scabies, is the principal responsible for potato common scab. This microorganism and related species are forming superficial lesions at the surface of potato tubers which affect both their production and commercial value. Because of the high frequency of this disease, reaching $85 \%$ for stocks in a survey realized in England (Dehnen-Schmutz et al., 2010), and because it is considered having only superficial effects, potato tubers affected by common scab are entering the commercial 
circuit and are consumed. This is not without raising some concerns as S. scabies and other Streptomyces involved in common scab are producing a large series of toxins, including thaxtomins, concanamycin, valinomycin, streptozotocin, bafilomycin, antimycins or nigericin (Bignell et al., 2014), which for the majority are encoded by a large pathogenicity island easily transferred between pathogenic and non-pathogenic strains (Kers et al., 2005; Lerat et al., 2009). Moreover, these toxins are heath stable and as Streptomyces hyphae are spreading deeply into the tuber (Loria et al., 2003), it is likely that these toxins can be found in cooked potato, particularly in products such as potato chips which are frequently presenting black spots relevant of Streptomyces infections (Myers et al., 2002; Knip et al., 2010). This is of potential importance as Streptomyces toxins, including thaxtomin A, nigericin, geldanamycin, tuncamycin and bafilomycin are suspected to be involved in acute forms of Type I diabetes (Myers et al., 2001; Myers et al., 2003; Bodin et al., 2015) and in chronic intestinal bowel diseases, including Crohn disease (Lowe et al., 2008).

In the present study, we investigated the distribution of these Streptomyces toxins in two types of potato tubers available in massmarket retailing. In complement, we used an in vitro model of differentiated enterocytes to document the potential intestinal resorption of these toxins.

\section{Materials and Methods}

\section{Chemicals}

Thaxtomin A, nigericin, tunicamycin, geldanamycin and bafilomycin A1 are presented in figure 1 with indication of their principal producing microorganisms. These toxins were obtained from Sigma Aldrich (Saint Quentin Fallavier, France). Ethanol, dimethyl sulfoxide (DMSO), acetone and diethyl oxide were from the same provider.

\section{Toxins assays in potato tubers}

Toxins were assayed in two common varieties of potato tubers, one of small size (Ratte $d u$ Touquet, mean weigh $72 \mathrm{~g}$ ) and one of medium size (Bintje, mean weigh $170 \mathrm{~g}$ ). They were obtained from a local commercial center. All potato tubers showed surface lesions typical of common scab. These surface lesions were collected for toxins assays. The flesh of the potato was also collected beneath the surface $(0.5 \mathrm{~cm}$ and 1 $\mathrm{cm}$ under the surface for small and medium size varieties, respectively) and at the centre of the tubers. Each sample was mixed with the solvent required for toxin extraction (Ethanol for thaxtomin A and nigericin, DMSO for tunicamycin and geldanamycin) at a ratio of $1 \mathrm{~mL}$ solvent / $100 \mu \mathrm{g}$ potato flesh. Samples were submitted to solvent extraction under gentle agitation $(15 \mathrm{rpm})$ over $24 \mathrm{~h}$ at room temperature. Before analysis insoluble elements were discarded by centrifugation. Toxins were quantified using a SCIEX API 3000 LCMS-MS system (Applied Biosystems) equipped with an electrospray ionization interface used to generate positive ions $[\mathrm{M}+\mathrm{H}]+$.

The analytes were separated on reversed phase column (Waters symmetry $\mathrm{C} 18,50 \mathrm{x}$ $2.1 \mathrm{~mm} ; 3.5 \mu$ particle size) with a gradient of mobile phase. Mobile phase A consisted in 20 $\mathrm{mM}$ ammonium acetate in water and mobile phase B of $0.1 \%$ of formic acid in acetonitrile. The following gradient was used: 0 to $1.5 \mathrm{~min}$ isocratic $\mathrm{A} / \mathrm{B} 85 \% \mathrm{~A} / 15 \% \mathrm{~B} ; 1.5$ to $2.0 \mathrm{~min}$ to reach $20 \% \mathrm{~A} / 80 \% \mathrm{~B}$ maintained until $4.0 \mathrm{~min}$, return to $85 \% \mathrm{~A} / 15 \% \mathrm{~B}$ in $0.1 \mathrm{~min}$ and stay isocratic during $2.9 \mathrm{~min}$. The column and autosampler temperature were maintained at $40^{\circ} \mathrm{C}$ and room temperature respectively. The mobile phase was eluted at $0.5 \mathrm{~mL} / \mathrm{min}$ using 
a Perkin Elmer 200 system. The optimized ion spray voltage and temperature were set at $5500 \mathrm{~V}$ and $500{ }^{\circ} \mathrm{C}$. The typical ion source parameters, declustering potential (DP), collision energy (CE), entrance potential (EP) and collision cell exit (CXP) potential were 50, 32, 9 and $20 \mathrm{~V}$ for thaxtomin A; 50, 60, 10 and $15 \mathrm{~V}$ for nigericin; 30, 30, 8 and $15 \mathrm{~V}$ for geldanamycin; 60, 28, 12 and $10 \mathrm{~V}$ for tunicamycin. Nitrogen gas was used for the nebulizer gas, curtain gas and collisionactivated dissociation gas, which were set at 10, 15 and 3 psi respectively. Quantification was performed by selected reaction monitoring of the protonated related product ion using the internal standard (IS) method with peak area ratios and a linear leastsquares regression curve with a weighting factor of $1 / x 2$. The internal standard was geldanamycin for thaxtomin $\mathrm{A}$, and geldanamycin for thaxtomin $\mathrm{A}$, no internal standard were used for nigericin nor tunicamycin. The mass transition used for thaxtomin A, nigericin, geldanamycin, and tunicamycin were $\mathrm{m} / \mathrm{z} 439.2$ _ 247.0, 747.4 729.6, 578.4 - 468.3 and 817.4 - 596.4 respectively, with a dwell time of 100 millisecond transition. Quadrupoles Q1 and Q3 were set on unit resolution. The analytical data were processed by analyst software (Version 1.4.1; Applied Bioystems).

\section{Cytotoxicity assays}

The human colonic adenocarcinoma cell line Caco-2/TC7 cells was employed to test the cytotoxicity of Streptomyces toxins and their solvents. These cells were used between passages 40-60. Caco-2/TC7 cells C were grown in Dulbecco's Modified Eagle's Medium (DMEM, Invitrogen) supplemented with $15 \%$ heat inactivated fetal calf serum (FCS), $2 \mathrm{mM}$ L-glutamine, $100 \mathrm{U} . \mathrm{ml}$ each of penicillin and streptomycin, and $1 \%$ nonessential amino acids. The cells were seeded and cultivated at $37^{\circ} \mathrm{C}$ in $5 \% \quad \mathrm{CO}_{2}-95 \%$ air atmosphere, in 24 wells tissue culture plates until confluence for cytotoxicity assay and on inserts $(6.4 \mathrm{~mm}$ diameter, $3 \mu \mathrm{m}$ pore size, Falcon) until full differentiation (28 days) for measurement of transepithelial resistance and toxins flow and permeability.

\section{Transepithelial resistance measurements}

Transepithelial resistance (TER) was used to monitor Caco-2/TC7 differentiation and confluence on inserts when the cells were grown in the absence or presence of Streptomyces toxins. Toxins were tested at concentrations close to their NOEL values determined in cytotoxicity assays. TER was measured at days 7, 21, 23, 25 and 28 using a Millicell Electrical Resistance System (Millipore Corp, Bedford, MA). The minimal TER value corresponding to confluent and fully differentiated Caco2/TC7 cells forming a continuous pseudo epithelium was $930 \Omega$.

\section{Measure of toxin flow and permeability}

Transepithelial permeation was used to evaluate the potential of Streptomyces toxins to cross the intestinal barrier. This parameter was measured using fully differentiated Caco2/TC7 cells grown after 28 days of culture on inserts $(6.4 \mathrm{~mm}$ diameter, $3 \mu \mathrm{m}$ pore size, Falcon) with $350 \mu \mathrm{L}$ DMEM in the apical compartment and $900 \mu \mathrm{L}$ in the basolateral compartment. The flow was calculated on the basis of the toxin concentration measured in the basolateral compartment after $24 \mathrm{~h}$, as previously described, and considering the volume of this compartment $(900 \mu \mathrm{L})$ and the surface of the insert $\left(0.3 \mathrm{~cm}^{2}\right)$. Permeability was obtained by division of the flow value by 3600 and by the toxin concentration used in the apical compartment. The amount of toxins measured in the apical and basolateral compartments after $24 \mathrm{~h}$ incubation was compared to the amount inoculated at the beginning of the 
experiment to evaluate any potential degradation or adsorption of tested molecules.

\section{Statistical analysis}

All results are expressed as means \pm standard error (SEM) calculated over a minimum of three independent experiments. Statistical differences were estimated using the Student's $t$ test and were noted as $\star, \star \star$ and $\star \star \star$ for $p$-values $<0.05,<0.01$ and $<0.001$, respectively. In confocal microscopy studies, the thickness of the biofilms was calculated from a minimum of 20 measures in different fields.

\section{Results and Discussion}

Cytotoxic activity of solvents required for Streptomyces toxins solubilisation

Thaxtomin A, nigericin, tunicamycin, geldanamycin and bafilomycin A1 can be only solubilised by solvents such as ethanol, DMSO, Diethyl ether or acetone. Then, in order to further investigate the activity of Streptomyces toxins on $\mathrm{Caco} 2 / \mathrm{TC} 7$ cells, it was necessary to control the cytotoxicity of these solvents. As shown in figure 2 when they were used at a final concentration under $1 \%$ these solvent had no or very limited cytotoxicity on Caco2/TC7 cells. Considering their optimal solubility, ethanol $1 \%$ was selected for solubilisation of thaxtomin A and nigericin in DMEM and DMSO $1 \%$ for solubilisation of tunicamycin, geldanamycin and bafilomycine A1.

\section{Assay of Streptomyces toxins in potato tubers}

The same solvents were used to extract each Streptomyces toxin from potato tubers. Toxins were assayed in scab surface lesions, in the flesh beneath the surface and at the centre of the tubers (Fig. 3). In the small variety of potato tubers (mean weight $72 \mathrm{~g}$ ), the concentration of thaxtomin A measured in surface lesions reached $3.3 \mathrm{ng} / 100 \mu \mathrm{g}$ of tissues. At a depth of $0.5 \mathrm{~cm}$, this mean concentration of thaxtomin A decreased to $2.93 \mathrm{ng} / 100 \mu \mathrm{g}$ but remained of $2.29 \mathrm{ng} /$ $100 \mu \mathrm{g}$ at the centre of the tubers. In the larger variety (mean weight $170 \mathrm{~g}$ ), the concentration of thaxtomin A decreased from $1.99 \pm \mathrm{xx} \mathrm{ng} / 100 \mu \mathrm{g}$ in surface lesions to $0.63 \mathrm{ng} / 100 \mu \mathrm{g}$ at the centre. Nevertheless, these measures reveal that significant amounts of the thaxtomin A are present in the flesh of potato tubers affected by common scab. Conversely, all other toxins were under the detection limits, i.e. $<5 \mathrm{ng} / 100 \mu \mathrm{g}$ for geldanamycin and < $10 \mathrm{ng} / 100 \mu \mathrm{g}$ for nigericin and tunicamycin. Bafilomycin was not assayed.

\section{Cytotoxic activity of Streptomyces toxins on Caco2/TC7 cells}

The cytotoxic activity of Streptomyces toxins was measured using the LDH assay and was compared to the basal level of cell death measured in control untreated cells $(15 \pm 1 \%)$ and to the maximal cell death (100\%) induced by administration of pure solvents (ethanol or DMSO). Thaxtomin A $100 \mu \mathrm{g} / \mathrm{mL}$ had a significant cytotoxic activity on Caco2/TC7 cells with a mean cell death of $25.1 \pm 2 \%$, whereas lower doses were not inducing any significant increase of cytotoxicity. Nigericin $50 \mu \mathrm{g} / \mathrm{mL}$ induced the death of $100 \%$ of Caco2/TC7 cells. At 5 $\mu \mathrm{g} / \mathrm{mL}$ the cytotoxicity of nigericin remained high $(58.8 \pm 6 \%)$ but it decreased to $20.2 \pm 3$ $\%$ when it was administered at a dose of 500 $\mathrm{ng} / \mathrm{mL}$. Even at the highest concentration tested $(100 \mu \mathrm{g} / \mathrm{mL})$ the cytotoxicity of geldanamycin remained in the same range as the control $(16.7 \pm 1 \%)$. Tunicamycin 100 $\mu \mathrm{g} / \mathrm{mL}$ was leading to the death of all Caco2/TC7 cells. When its concentration was reduced to $10 \mu \mathrm{g} / \mathrm{mL}$ the cytoxicity of 
tunicamycin decreased to $22 \pm 1 \%$ and to 16.5 $\pm 2 \%$ when it was administered at a concentration of $1 \mu \mathrm{g} / \mathrm{mL}$. Bafilomycin A1 $1 \mu \mathrm{g} / \mathrm{mL}$ was associated to the death of $43.4 \pm$ $4 \%$ of the cells. Lower concentrations allowed to reduce its cytotoxicity but even at the lower dose tested $(1 \mathrm{ng} / \mathrm{mL})$ it remained significantly higher than the control $(23.6 \pm 1$ \%) (Fig. 4).

Effect of sub-lethal concentrations of Streptomyces toxins on Caco2/TC7 cells differentiation

Toxins were tested at concentrations close to their NOEL values on Caco2/TC7 cells as determined previously: $10 \mu \mathrm{g} / \mathrm{mL}$ for thaxtomin A, $500 \mathrm{ng} / \mathrm{mL}$ for nigericin, 100 $\mu \mathrm{g} / \mathrm{mL}$ for geldanamycin and $1 \mu \mathrm{g} / \mathrm{mL}$ for tunicamycin. Bafilomycin A1, being toxic even at the lower dose administered, was not tested. As previously observed, complete differentiation of Caco2/TC7 cells was not achieved before 28 days of culture on inserts (Fig. 5). TER measured after cell growth in the presence of low doses of solvents (ethanol or DMSO 1\%) required to solubilize toxins was higher suggesting that cells adapted to solvents by reducing their membrane permeability. None of the toxins tested was decreasing the TER of cells monolayers after 28 days of cultures in their presence indicatig that, when employed at sublethal doses thaxtomin A, nigericin, geldanamycin and tunicamycin are not affecting the differentiation of $\mathrm{Caco} 2 / \mathrm{TC} 7$ cells.

Measure of toxin flow and permeability of Streptomyces toxins through fully differentiated Caco2/TC7 cells monolayers

Thaxtomin A was presenting a significant flow $(2.83 \pm 0.34 \mathrm{ng} / \mathrm{h} / \mathrm{cm} 2$, Fig. 6A) and permeability $(2.91 \pm 0.4 \mathrm{~cm} / \mathrm{s}$, Fig. 6B) on differentiated Caco2/TC7 epithelium after 24 $\mathrm{h}$ incubation on inserts. The cumulated mass of thaxtomin A recovered in the apical and basolateral compartments of inserts was lower $(-13.9 \pm 1.2 \%)$ than the initial mass of the toxin layered at the onset of the experiment suggesting a partial degradation or adsorption of the toxin on the cells. Nevertheless, the values measured are consistent with a real flow of thaxtomin through the $\mathrm{Caco} 2 / \mathrm{TC} 7$ cells epithelium. Nigericin was not detected in the basolateral compartment of inserts after $24 \mathrm{~h}$ incubation and the apparent resulting flow and permeability were null. However, nigericin was also undetectable in the apical compartment indicating that in our experimental conditions this toxin was not sufficiently stable for measuring its flow and permeability. In the case of geldanamycin and tunicamycin a marked difference was also observed between the amount of the toxin initially administered and that recovered in total after $24 \mathrm{~h}(-67,0 \pm 4.7 \%$ and $-76.5 \pm$ $9.8 \%$, respectively) suggesting that these toxins were also adsorbing or were actively degraded by Caco2/TC7 cells. However, flow $(0.75 \pm 0.1 \mathrm{ng} / \mathrm{h} / \mathrm{cm} 2$ and $0.09 \pm 0.18$ $\mathrm{ng} / \mathrm{h} / \mathrm{cm} 2$ for geldanamycin and tunicamycin, respectively) and permeability values $(0.531 \pm$ $0.2 \mathrm{~cm} / \mathrm{s}$ and $12.1 \pm 0.5 \mathrm{~cm} / \mathrm{s}$ for geldanamycin and tunicamycin, respectively) remained usable indicating that both toxins were capable to cross the Caco2/TC7 epithelial model.

Food safety is a major concern, especially for products of common consumption which can lead to important cumulative amounts of toxins in case of contamination. This is potentially the case of potato with a mean consumption of 60 and $87.5 \mathrm{~kg} / \mathrm{capita}$ in North America and Europe (FAOSTAT, 2008). Indeed, potatoes are very frequently affected by a disease caused by different species of Streptomyces designated as "common scab". This disease can lead to important production losses (Hill and Lazarovits, 2005) and tubers showing marks 
of common scab are frequently found in the commercial circuit. As in its mild form this disease affects apparently only the surface of the tuber, they can be easily consumed. However, Streptomyces hyphae might penetrate beneath the surface of the tubers (Clark \& Matthews, 1987; Lauria et al., 2003) and most of the toxins produced by these microorganisms are thermostable. Then, consumers should be exposed to these toxins through cooked or transformed potato products.

In the present work we investigated the distribution of thaxtomin $\mathrm{A}$, nigericin, tunicamycin, geldanamycin and bafilomycin A1, five toxins produced by $S$. scabies, the principal germ responsible for common scab, and related species. As those toxins are not soluble in water or cell culture medium, we selected two solvents, i.e. ethanol and DMSO $1 \%$, allowing to solubilize and extract toxins from potato flesh and without intrinsic toxicity that should interfere with the effect of Streptomyces toxins on Caco2/TC7 cells. The colon carcinoma Caco 2 cell line is the only human epithelial cell line which differentiates spontaneously into enterocytes when grown in standard culture conditions including formation of microvilli and specific enzymatic activities at the apical surface (Turk et al., 2004) and provides a simplified model to investigate intestinal cells differentiation and permeability.

Assay of the toxins in two varieties of potato tubers collected randomly in the commercial circuit revealed that thaxtomin A is not only localized in surface scab lesions, but can be detected in significant amounts beneath the surface and just to the centre of the tuber. Other toxins studied, i.e. nigericin, tunicamycin, geldanamycin and bafilomycin A1, were present at concentrations below the detection limits of our analytical tools. However, this is not excluding a potential effect of these molecules as additive or even synergistic effects of these compounds have been described (Hiltunen et al., 2006; Duke \& Dayan, 2011). Even when studied independently, most of these molecules showed significant toxicity on Caco2/TC7 cells. Thaxtomin A $100 \mu \mathrm{g} / \mathrm{mL}$ induced a significant increase of cell death but reduced concentrations under $10 \mu \mathrm{g} / \mathrm{mL}$ were without effect. The cytotoxicity of nigericin was high (100 \% cell death at $50 \mu \mathrm{g} / \mathrm{mL}$ ) and it was necessary to reduce the concentration to 500 $\mathrm{ng} / \mathrm{mL}$ to get closer to the NOEL value. Tunicamycin also showed high toxicity and its NOEL value was in the same range (1 $\mu \mathrm{g} / \mathrm{mL})$. Geldanamycin was the only molecule which did not show any toxicity in our experimental conditions, even at the highest dose tested $(100 \mu \mathrm{g} / \mathrm{mL})$. Conversely, the toxicity of bafilomycin A1 remained significant at all tested doses, including the lower $(1 \mathrm{ng} / \mathrm{mL})$, The toxicity of Thaxtomin $\mathrm{A}$ and other thaxtomins has been almost exclusively investigated in vegetals where these molecules cause cell hypertrophy and apoptosis (King \& Calhoun, 2009). To our knowledge, until now the unique study on the toxicity of thaxtomins in animals was realized on spermatozoids where no acute effect on mobility was observed (Kotiaho et al., 2008) but other potential effects were not studied. Nigericin is a teratogenic compound (VedelMacrander \& Hood, 1986) and its toxicity (LD50) is reaching $2.5 \mathrm{mg} / \mathrm{kg}$ by parenteral administration in mouse (Harned et al., 1951). This is coherent with the high toxicity of this molecule on Caco2/TC7 cells. Tunicamycin is showing apoptotic activity and its toxicity on developing cells has been also well documented (Balcan \& Arslan, 2015). Geldanamycin is an inhibitor of the chaperone protein Hsp90 (Han et al., 2014) with apoptotic activity. In this regard its total absence of acute toxicity on $\mathrm{Caco} 2 / \mathrm{TC} 7$ cells was unexpected. 
Fig.1 Structure of the more abundant toxins produced by Streptomyces scabies and related species

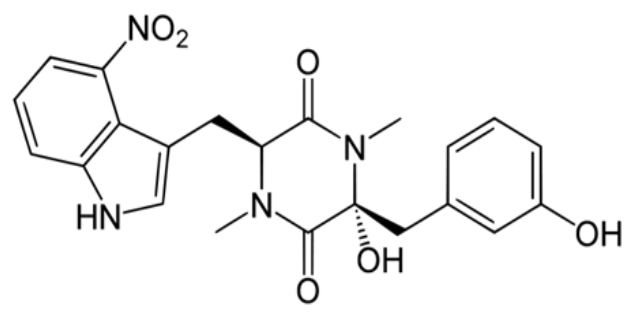

Thaxtomin A (+++ S. scabies)

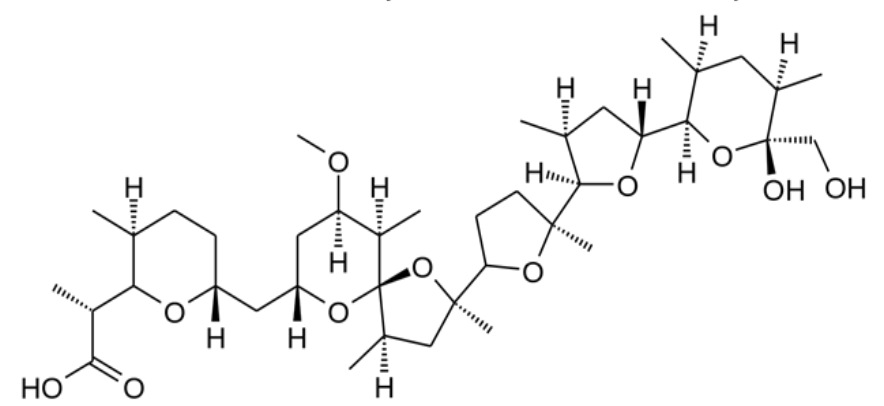

Bafilomycin A1 (+++ S. griseus, S. scabies)

Nigericin (+++ S. hygroscopicus, S. scabies)
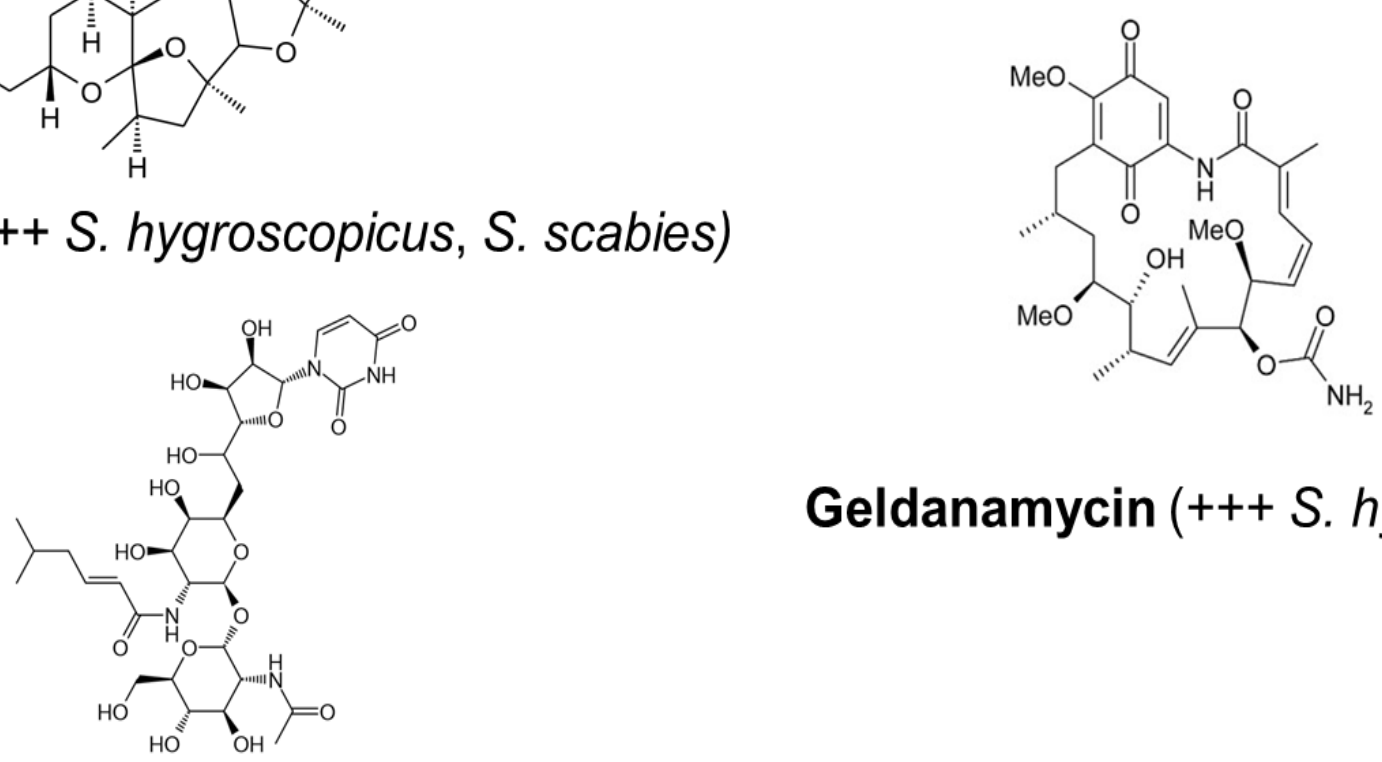

Geldanamycin (+++ S. hygroscopicus)

Tunicamycin (+++ S. lysosuperificus) 
Fig.2 Cytotoxic activity of solvents required for Streptomyces toxins solubilisation on $\mathrm{CaCo} 2 / \mathrm{TC} 7$ cells. $(\star \star=\mathrm{p}<0.01 ; \star \star \star=\mathrm{p}<0.001)$

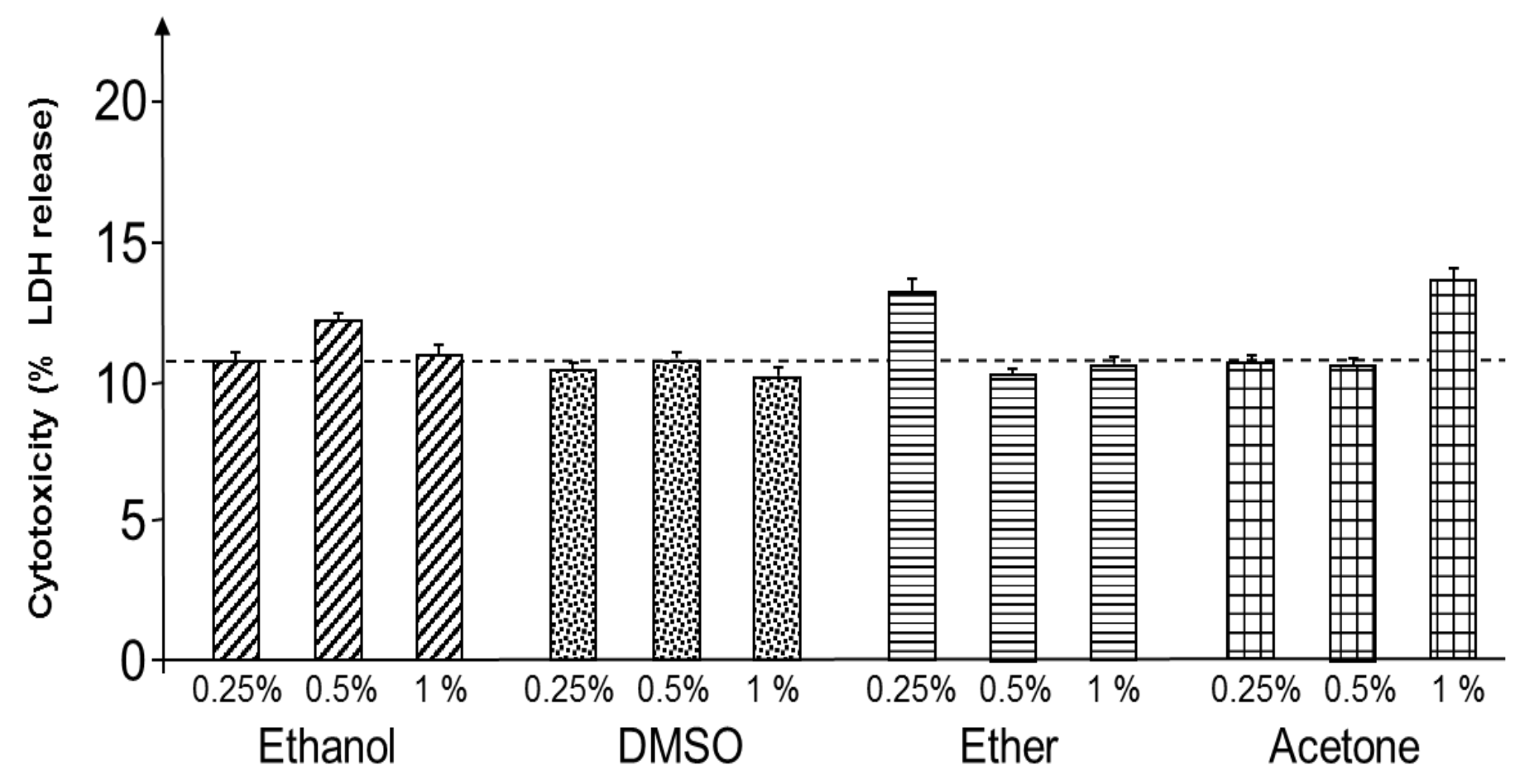


Fig.3 Concentrations of Thaxtomin A, Nigericin, Geldanamycin and Tunicamycin measured in common scab lesions, sub-peripheral areas and at the center of two varieties of potato tubers

Small size potato tubers

(Variety Ratte du Touquet)

(Mean weight: $72 \mathrm{~g}$ )
Medium size potato tubers

(Variety Bintje)

(Mean weight: $170 \mathrm{~g}$ )

\section{Thaxtomin A}

$3.3 \mathrm{ng} / 100 \mu \mathrm{g}$ $2.93 \mathrm{ng} / 100 \mu \mathrm{g}$

$2.29 \mathrm{ng} / 100 \mu \mathrm{g}$

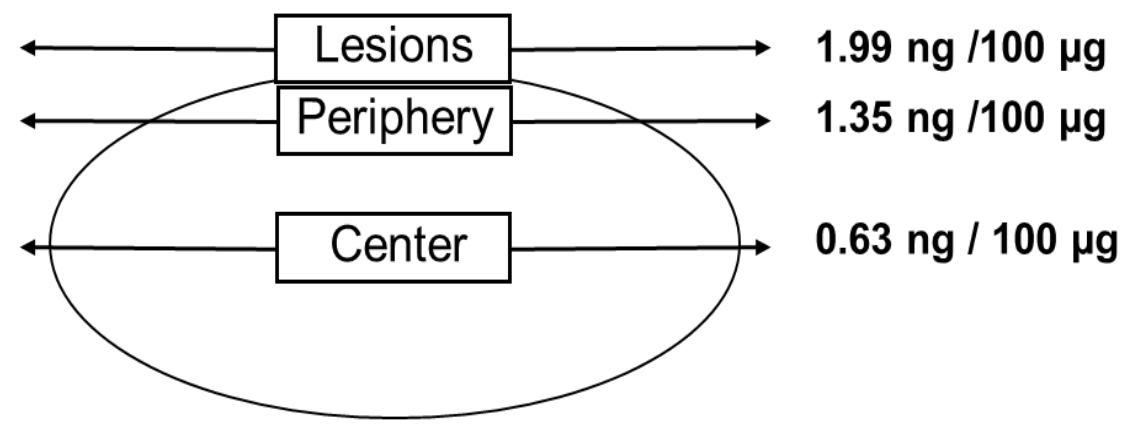

$$
\begin{array}{ll}
\text { Nigericin } & :<10 \mathrm{ng} / 100 \mu \mathrm{g} \\
\text { Geldanamycin } & :<5 \mathrm{ng} / 100 \mu \mathrm{g} \\
\text { Tunicamycin } & :<10 \mathrm{ng} / 100 \mu \mathrm{g}
\end{array}
$$


Fig.4 Cytotoxic activity of Thaxtomin A, Nigericin, Geldanamycin, Tunicamycin and Bafilomycin A1 on CaCo2/TC7 cells. ( $\star \star=p$ $<0.01 ; \star \star \star=\mathrm{p}<0.001)$

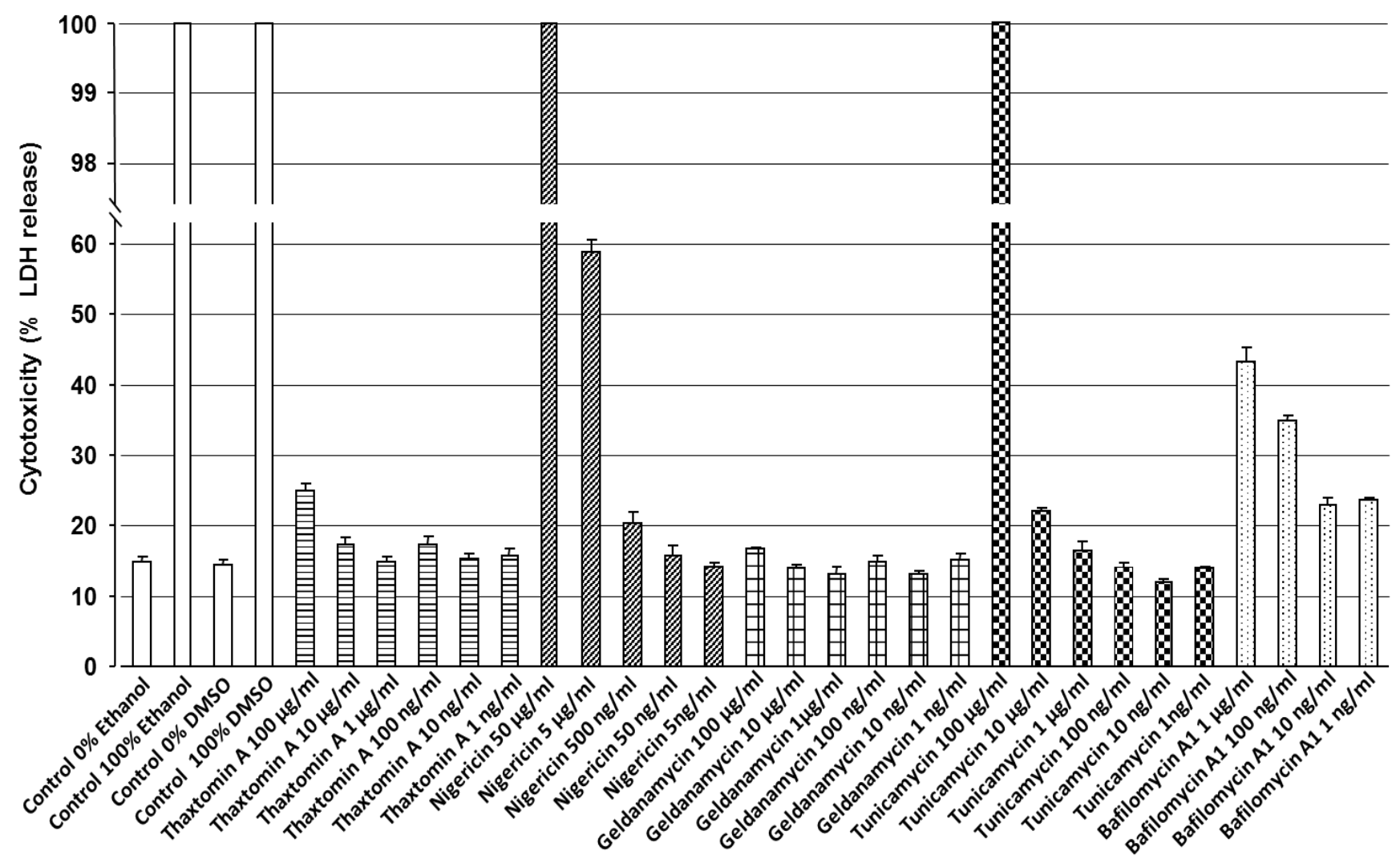


Int.J.Curr.Microbiol.App.Sci (2017) 6(5): 1662-1676

Fig.5 Effect of Thaxtomin A, Nigericin, Geldanamycin and Tunicamycin on the trans-epithelial resistance of CaCo2/TC7 monolayers during differentiation over 28 days

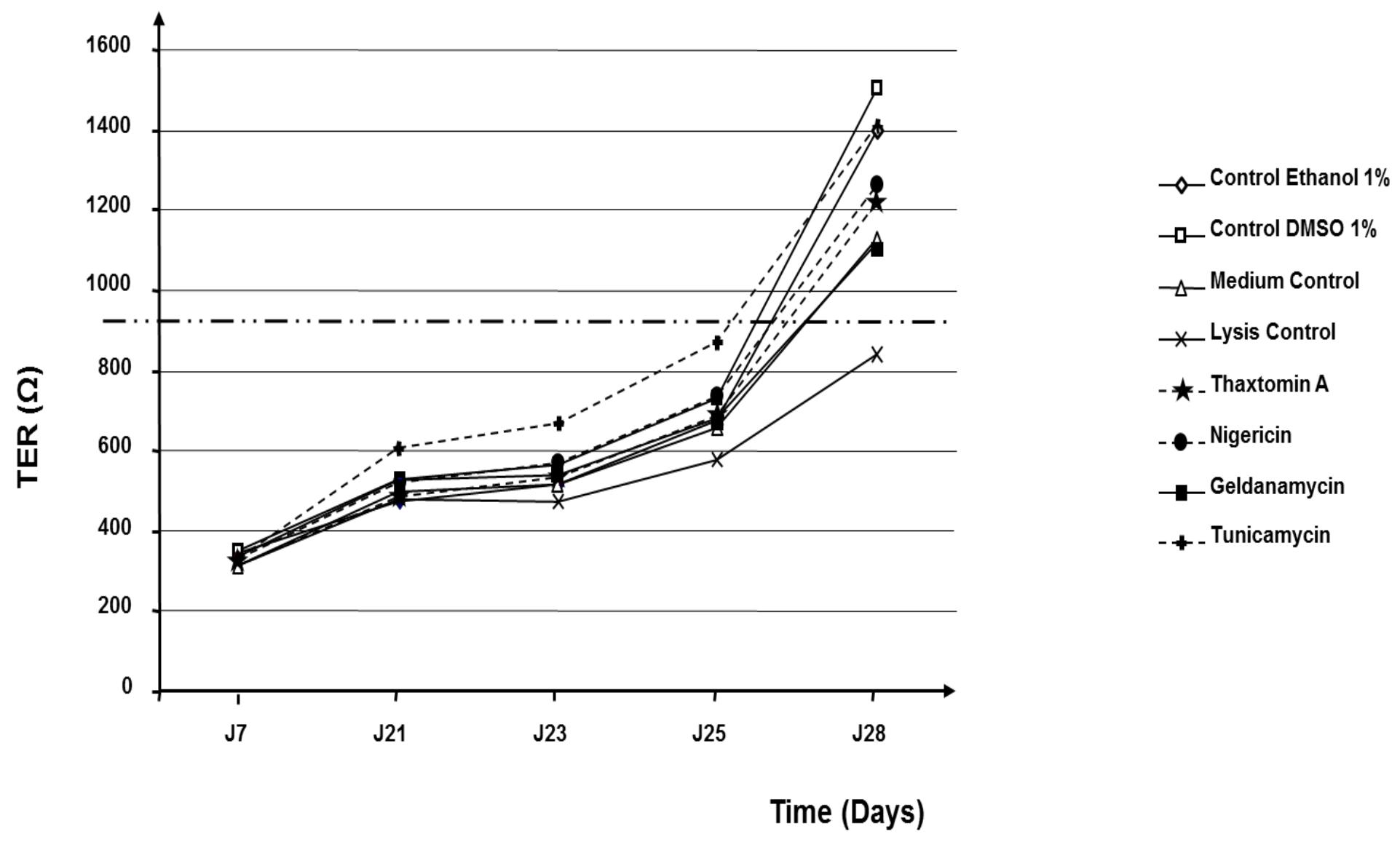


Fig.6 Mean flux (A) and permeability (B) of Thaxtomin A, Nigericin, Geldanamycin and Tunicamycin through fully differenciated Caco2/TC7 intestinal like epithelium.

(NS = non significant; $\star=\mathrm{p}<0.05 ; \star \star=\mathrm{p}<0.01 ; \star \star \star=\mathrm{p}<0.001)$

A

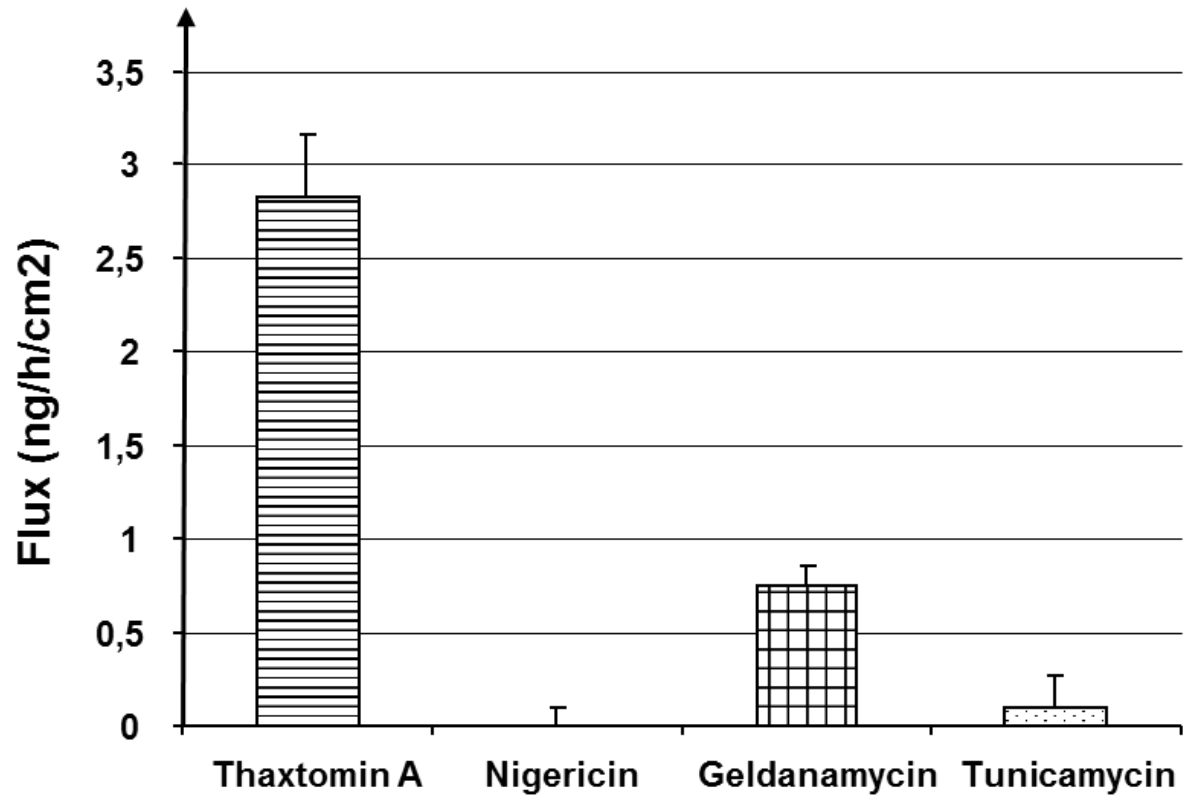

B

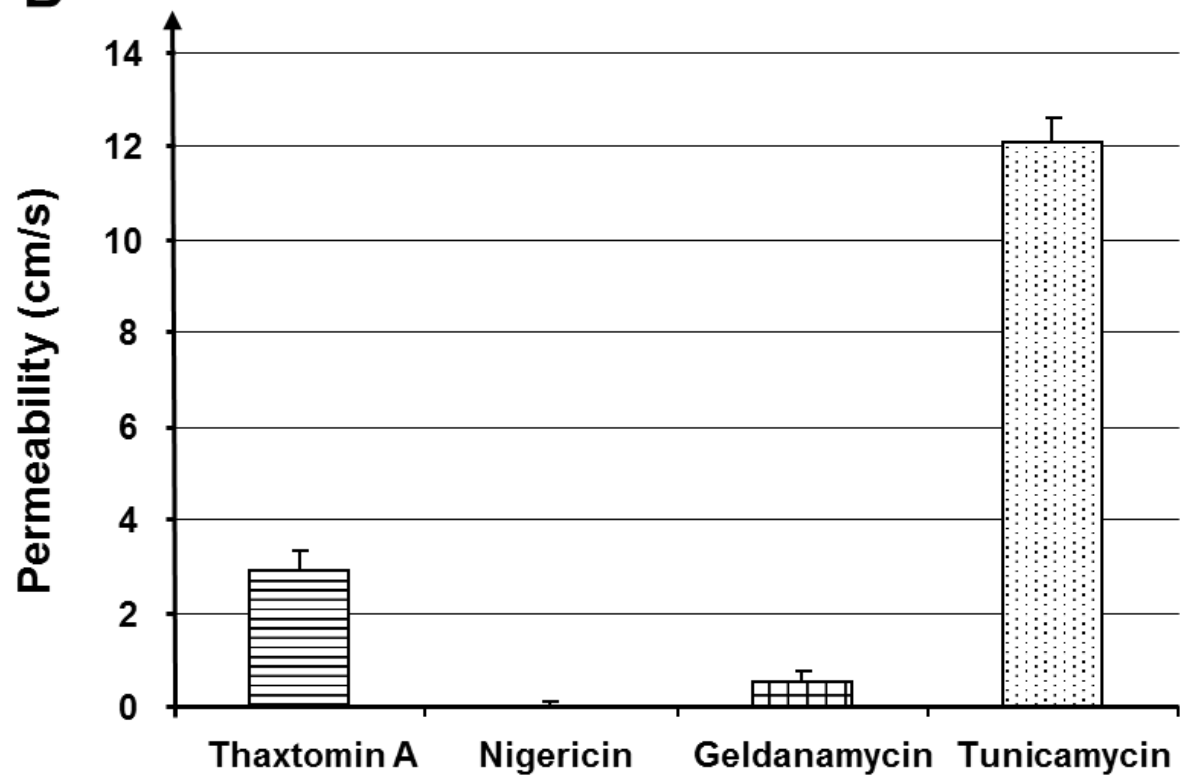


Conversely, the cytotoxicity of bafilomycin A1 is coherent with its strong apoptotic activity (Kinoshita et al., 1996). In order to avoid any acute effect and reflect the conditions of chronic exposure to low doses of these toxins, their effect on Caco2/TC7 cells differentiation was investigated in the range of their NOEL values, i.e. $10 \mu \mathrm{g} / \mathrm{mL}$ for thaxtomin A, $500 \mathrm{ng} / \mathrm{mL}$ for nigerin and 1 $\mu \mathrm{g} / \mathrm{mL}$ for tunicamycin. Geldanamycin was used at the maximal dose tested in cytotoxicity studies (100 $\mu \mathrm{g} / \mathrm{mL})$ and bafilomycin A1 was excluded from the rest of the study because of its significant toxicity at alltested doses. Caco2/TC7 cells were exposed to the toxins over 28 days all along their differentiation into enterocytes and assembly into an epithelium. Differentiation was monitored by measuring the evolution of TER. The TER value of tunicamycin treated cells showed a marginal increase between $\mathrm{J} 7$ and $\mathbf{J} 21$ in comparison to the control and all other tested conditions. However, after 28 days of culture, the TER value of all epithelia was above $930 \Omega$ indicating that they were fully differentiated and that, at the sub-lethal values employed, none of the toxins studied had a significant effect of the differentiation of Caco2/TC7 cells. In this condition it was possible to investigate the flux of these toxins through the differentiated epithelia.

Despite a partial loss due to adsorption or degradation a significant flow of thaxtomin A, geldanamycin and tunicamycin was measured through the reconstructed enterocyte epithelium. Thaxtomin A was presenting a significant flow $(2.83 \pm 0.34 \mathrm{ng} / \mathrm{h} / \mathrm{cm} 2$, Fig. $6 \mathrm{~A})$ and permeability $(2.91 \pm 0.4 \mathrm{~cm} / \mathrm{s}$, Fig. 6B) on differentiated $\mathrm{Caco} 2 / \mathrm{TC} 7$ epithelium after $24 \mathrm{~h}$ incubation on inserts. The cumulated mass of thaxtomin A recovered in the apical and basolateral compartments of inserts was lower $(-13.9 \pm 1.2 \%)$ than the initial mass of the toxin layered at the onset of the experiment suggesting a partial degradation or adsorption of the toxin on the cells. Nevertheless, the values measured are consistent with a real flow of thaxtomin through the Caco2/TC7 cells epithelium.

Nigericin was not detected in the basolateral compartement of inserts after $24 \mathrm{~h}$ incubation and the apparent resulting flow and permeability were null. However, nigericin was also undetectable in the apical compartment indicating that in our experimental conditions this toxin was not sufficiently stable for measuring its flow and permeability. In the case of geldanamycin and tunicamycin a marked difference was also observed between the amount of the toxin initially administered and that recovered in total after $24 \mathrm{~h}(-67,0 \pm 4.7 \%$ and $-76.5 \pm$ $9.8 \%$, respectively) suggesting that these toxins were also adsorbing or were actively degraded by $\mathrm{Caco} 2 / \mathrm{TC} 7$ cells. However, the flow $(0.75 \pm 0.1 \mathrm{ng} / \mathrm{h} / \mathrm{cm} 2$ and $0.09 \pm 0.18$ $\mathrm{ng} / \mathrm{h} / \mathrm{cm} 2$ for geldanamycin and tunicamycin, respectively) and permeability values $(0.531 \pm$ $0.2 \mathrm{~cm} / \mathrm{s}$ and $12.1 \pm 0.5 \mathrm{~cm} / \mathrm{s}$ for geldanamycin and tunicamycin, respectively) remained usable, indicating that both toxins were capable to cross the $\mathrm{Caco} 2 / \mathrm{TC} 7$ epithelial model.

In conclusion, this study reveals that in potato affected by common scab a toxin such as thaxtomin A diffuses deeply just to the center of the tuber. Although other studied toxins were below the detection limit, this is indicating that Streptomyces toxins can be potentially present in the whole flesh of infected tubers. These toxins are heath stable, and are presenting significant cytotoxicity on Caco2/TC7 enterocytes but appear having a limited impact on the intestinal barrier. In contrast, in vitro studies suggest that even at sub-lethal doses thaxtomin A, geladanamycin and tunicamycin can cross the intestinal epithelium. The risk of acute toxicity is very limited but chronic exposure to this toxin could lead to sensitization. The present results 
deserve an in vivo evaluation of the risk associated to Streptomyces toxins.

\section{Acknowledgements}

This study was supported by Evreux Portes de Normandie, Region Normandie and European Union (FEDER).

\section{References}

Balcan, E., and Arslan, O. 2015. Effect of tunicamycin on glycosaminoglycans and laminins in embryonic and postnatal thymic tissues. Anal. Quantitative Cytopathol. Histopathol., 37: 252-266.

Bignell, D.R.D., Fyans, J.K., Cheng, Z. 2013. Phytotoxins produced by plant pathogenic Streptomyces species. $J$. Appl. Microbiol., 116: 223-235.

Bodin, J., Stene, L.C., Nygaard, U.C., 2015. Can exposure to environmental chemicals increase the risk of diabetes type 1 development? BioMed Res. Int., Article ID 208947, 19 pages.

Clark, C.A., Matthews, S.W. 1987. Histopathology of sweet potato root infection by Streptomyces ipomea. Phytopathol., 77: 1418-1423.

Dehnen-Schmutz, K., MacLeod, A., Reed, P., Mills, P.R. 2010. The role of regulatory mechanisms for control of plant diseases and food security. Case studies from potato production in Britain. Food Security, 2: 233-245.

Duke, S.O., and Dayan, F.E. 2011. Modes of action of microbially-produced phytotoxins. Toxins, 3: 1038-1064.

Food and Agriculture Organization of the United Nations Statistics Division FAOSTAT. 2008. http://www.fao.org/potato2008/en/world/

Han, F.F., Li, L., Shang, B.Y., Shao, R.G., Zhen, Y.S., 2014. Hsp90 inhibitor geldanamycin enhances the antitumor efficacy of enediyne lidamycin in association with reduced DNA damage repair. Asian Pacific J. Cancer Prevention, 15: 7043-7048.

Harned, R.L., Hidy, P.H., Corum, C.J., Jones, K.L., 1951. Nigericin, a new crystalline antibiotic from an unidentified Streptomyces. Antibiotics and Chemother., 1: 594-596.

Hill, J., Lazarovits, G. 2005. A mail survey of growers to estimate potato common scab prevalence and economic loss in Canada. Canadian J. Plant Pathol., 27: 46-52.

Hiltunen, L.H., Laakso, I., Chobot, V., Hakala, K.S., Weckman, A., Valkonen, J.P. 2006. Influence of thaxtomins in different combinations and concentrations on growth of micropropagated potato shoot cultures. J. Agri. Food Chem., 54: 3372-3379.

Kämpfer, P. 2006. The Family Streptomycetaceae, Part I: Taxonomy. In Dworkin, M., Falkow, S., Rosenberg, E., Schleifer, K-H., Stackebrandt, E., Eds. The Prokaryotes, pp. 538-604.

Kers, J.A., Cameron, K.D., Joshi, M.V., Bukhalid, R.A., Morello, J.E., Wach, M.J., Gibson, D.M., Loria, R., 2005. A large, mobile pathogenicity island confers plant pathogenicity on Streptomyces species. Mol. Microbiol., 55: 1025-1033.

King, R.R., Calhoun, L.A., 2009. The thaxtomin phytotoxins: sources, synthesis, biosynthesis, biotransformation and biological activity. Phytochem., 70: 833-841.

Kinoshita, K., Waritani, T., Noto, M., Takizawa, K., Minemoto, Y., Nishikawa, A., Ohkuma, S., Nishikawa, Y., 1996. Bafilomycin A1 induces apoptosis in PC12 cells independently of intracellular pH. FEBS Lett., 398: 6166. 
Knip, M., Virtanen, S.M., Åkerblom, H.K., 2010. Infant feeding and the risk of type 1 diabetes. American J. Clin. Nutri., 91: 1506S-1513S.

Kotiaho, M., Aittamaa, M., Andersson, M., Mikkola, R., Valkonen, J., SalkinojaSalonen, M., 2008. Antimycin Aproducing nonphytopathogenic Streptomyces turgidiscabies from potato. J. Appl. Microbiol., 104: 13321340.

Lerat, S., Simao-Beaunoir, A.M., Beaulieu, C., 2009. Genetic and physiological determinants of Streptomyces scabies pathogenicity. Mol. Plant Pathol., 10: 579-585.

Loria, R., Coombs, J., Yoshida, M., Kers, J., Bukhalid, R. 2003. A paucity of bacterial root diseases: Streptomyces succeeds where others fail. Physiol. Mol. Plant Pathol., 62: 65-72.

Lowe, A-M., Yansouni, C.P., Behr, M.A., 2008. Causality and gastrointestinal infections: Koch, Hill, and Crohn's. Lancet Infect. Dis., 8: 720-726.

Myers, M.A., Mackay I.R., Rowley, M.J., Zimmet, P.Z. 2001. Dietary microbial toxins and type 1 diabetes. A new meaning for seed and soil. Diabetologia, 44: 1199-1200.

Myers, M.A., Mackay, I.R., Zimmet, P., 2002. Dietary toxins: digging up the dirt on vegetables. Diabetes Voice, 47: 3537.

Myers, M.A., Hettiarachchi, K.D., Ludeman, J.P., Wilson, A.J., Wilson, C.R., Zimmet, P.Z., 2003. Dietary microbial toxins and type 1 diabetes. Annals of the New York Academy of Sci., 1005: 418422.

Turck, N., Richert, S., Gendry, P., Stutzmann, J., Kedinger, M., Leize, E., SimonAssmann, P., Van Dorsselaer, A., Launay, J.F., 2004. Proteomic analysis of nuclear proteins from proliferative and differentiated human colonic intestinal epithelial cells. Proteomics, 4: 93-105.

Vedel-Macrander, G.C., and Hood, R.D., 1986. Teratogenic effects of nigericin, a carboxylic ionophore. Teratol., 33: 4751.

Watve, M.G., Tickoo, R., Jog, M.M., Bhole, B.D., 2001. How many antibiotics are produced by the genus Streptomyces?. Arch. Microbiol., 176: 386-90.

\section{How to cite this article:}

Camille Leclerc, Arthur Zebré, Jérémy Enault, Pierre-Jean Racine, Sandra Leblanc, Nathalie Connil, Pascal Svinareff and Marc G.J. Feuilloley. 2017. Evaluation of Streptomyces Common Scab Toxins Diffusion in Potato Tubers and through the Intestinal Barrier. Int.J.Curr.Microbiol.App.Sci. 6(5): 1662-1676. doi: https://doi.org/10.20546/ijcmas.2017.605.181 